\title{
Conversion of calcium sulphide to calcium carbonate during the process of recovery of elemental sulphur from gypsum waste
}

\author{
M. de Beer ${ }^{\mathrm{a}, \mathrm{b}^{*}}$, J.P. Maree ${ }^{\mathrm{c}}$, L. Liebenberg ${ }^{\mathrm{b}}$, and F.J. Doucet ${ }^{\mathrm{d}^{*}}$ \\ a DST/CSIR National Centre for Nanostructured Materials, Council for Scientific and Industrial Research, PO Box 395, \\ Pretoria 0001, Republic of South Africa. \\ ${ }^{b}$ Centre for Research and Continued Engineering Development, North-West University, Pretoria, Republic of South Africa \\ ' Department of Environmental, Water and Earth Science, Faculty of Science, Tshwane University of Technology, Private \\ Bag X680, Pretoria 0001, Republic of South Africa \\ d Industrial Mineralogy Laboratory, Council for Geoscience, Private Bag X112, Pretoria 0001, Republic of South Africa. \\ * Corresponding authors: mdebeer@csir.co.za (M. de Beer; Tel: +27 (0) 841 4987); fdoucet@geoscience.org.za (F.J. \\ Doucet; Tel: +27 (0) 841 1300)
}

\begin{abstract}
The production of elemental sulphur and calcium carbonate $\left(\mathrm{CaCO}_{3}\right)$ from gypsum waste can be achieved by thermally reducing the waste into calcium sulphide ( $\mathrm{CaS}$ ), which is then subjected to a direct aqueous carbonation step for the generation of hydrogen sulphide $\left(\mathrm{H}_{2} \mathrm{~S}\right)$ and $\mathrm{CaCO}_{3} . \mathrm{H}_{2} \mathrm{~S}$ can subsequently be converted to elemental sulphur via the commercially available chemical catalytic Claus process. This study investigated the carbonation of CaS by examining both the solution chemistry of the process and the properties of the formed carbonated product. CaS was successfully converted into $\mathrm{CaCO}_{3}$; however, the reaction yielded low-grade carbonate products (i.e. $<90$ mass \% as $\mathrm{CaCO}_{3}$ ) which comprised a mixture of two $\mathrm{CaCO}_{3}$ polymorphs (calcite and vaterite), as well as trace minerals originating from the starting material. These products could replace the Sappi Enstra $\mathrm{CaCO}_{3}$ (69 mass \% $\mathrm{CaCO}_{3}$ ), a by-product from the paper industry which is used in many full-scale AMD neutralisation plants but is becoming insufficient. The insight gained is now also being used to develop and optimize an indirect aqueous $\mathrm{CaS}$ carbonation process for the production of high-grade $\mathrm{CaCO}_{3}$ (i.e. $>99$ mass \% as $\mathrm{CaCO}_{3}$ ) or precipitated calcium carbonate (PCC).
\end{abstract}

\section{Keywords}

Gypsum waste; carbonation; valorisation; calcium carbonate; calcium sulphide

\section{Introduction}

The chemical manufacturing industry and the industrial waste remediation sector generate millions of tons of gypsum-rich solid wastes and sludge. Those include processes such as phosphoric, hydrofluoric, citric and boric acid production, treatment of waste from desulphurisation of flue gases from coal-fired power stations, ore smelting, and acid mine water treatment. Most of this poorquality gypsum is generally regarded as unsuitable for further use, and is therefore stored in large stockpiles. The remediation of acid mine drainage (AMD) using alkaline-based processes gives rise to a gypsum-rich sludge which requires proper environmental management [1] in order to prevent serious environmental pollution such as airborne dust and contamination of groundwater resources. An alternative approach to the often expensive management of stockpiles is to treat the sludge with the aim of converting it into potentially useful products [2]. 
Gypsum waste can represent a good resource for the recovery of sulphur (S) and calcium carbonate $\left(\mathrm{CaCO}_{3}\right)$ [3]. Elemental sulphur is an essential raw material for many manufacturing industries such as fertilisers, acids, steel, petroleum, insecticides, titanium dioxide, and explosives [4]. Its application as an alternative feedstock for the production of polymeric materials has also been recently suggested [5]. $\mathrm{CaCO}_{3}$ also has many uses in a wide variety of industrial and commercial applications, either as ground calcium carbonate (GCC; for instance in the manufacturing of concrete or Portland cement, for producing lime to be used in soil stabilization and acid neutralization, for water treatment, and flue gas desulphurization [6]) or as precipitated calcium carbonate (PCC; for instance as a filler and coating pigment in paper, plastics, paints, rubbers and adhesives $[7,8]$.

A multi-step process for the recovery of sulphur and $\mathrm{CaCO}_{3}$ from gypsum waste has been proposed [3]. It involves the following three steps:

(i) Thermal reduction $\left(900^{\circ} \mathrm{C}-1100^{\circ} \mathrm{C}\right)$ of gypsum waste to produce calcium sulphide (CaS) using reducing agents (e.g. solid carbon materials such as coal or activated carbon (Eq. (1); $[9,10])$, carbon monoxide gas (Eq. (2); [11,12]), or hydrogen gas (Eq. (1); [13])).

$$
\begin{aligned}
& \mathrm{CaSO}_{4}(\mathrm{~s})+2 \mathrm{C}(\mathrm{s}) \rightarrow \mathrm{CaS}(\mathrm{s})+2 \mathrm{CO}_{2}(\mathrm{~g}) \\
& \mathrm{CaSO}_{4}(\mathrm{~s})+4 \mathrm{CO}(\mathrm{g}) \rightarrow \mathrm{CaS}(\mathrm{s})+4 \mathrm{CO}_{2}(\mathrm{~g}) \\
& \mathrm{CaSO}_{4}(\mathrm{~s})+4 \mathrm{H}_{2}(\mathrm{~g}) \rightarrow \mathrm{CaS}(\mathrm{s})+4 \mathrm{H}_{2} \mathrm{O}(\mathrm{l})
\end{aligned}
$$

(ii) Direct aqueous carbonation of $\mathrm{CaS}$ to produce hydrogen sulphide $\left(\mathrm{H}_{2} \mathrm{~S}\right)$ and $\mathrm{CaCO}_{3}$. The reaction proceeds according to Eq. (4).

$$
\mathrm{CaS}(\mathrm{s})+\mathrm{H}_{2} \mathrm{O}+\mathrm{CO}_{2}(\mathrm{~g}) \rightarrow \mathrm{H}_{2} \mathrm{~S}(\mathrm{~g})+\mathrm{CaCO}_{3}(\mathrm{~s})
$$

(iii) Recovery of elemental sulphur from $\mathrm{H}_{2} \mathrm{~S}$ via the commercially available chemical catalytic Claus process [14].

Two steps of the process (steps (i) and (iii)) are fairly well understood [15,16], but little effort has been given to the investigation of the second step, except for two independent studies on the stripping of $\mathrm{H}_{2} \mathrm{~S}$ [3], and on the conversion of $\mathrm{CaS}$ into $\mathrm{H}_{2} \mathrm{~S}$ and $\mathrm{CaCO}_{3}$ but making use of methyldiethanolamine (MDEA) as a $\mathrm{CO}_{2}$ and $\mathrm{H}_{2} \mathrm{~S}$ solubility catalyst [17]. The primary objective of this paper, which focuses on step (ii) above (eq. (4)), was therefore to provide a better understanding of the direct aqueous carbonation reaction between $\mathrm{CaS}$ and $\mathrm{CO}_{2}$, by investigating both the solution chemistry of the process and the properties of the formed carbonated product.

\section{Experimental section}

\subsection{Materials preparation and characterization}

A calcium sulphide-rich calcine powder (hereafter denominated $\mathrm{CaS}_{r}$ ) was produced from a gypsum waste sample collected at an acid mine water neutralisation plant in South Africa. $\mathrm{CaS}_{r}$ was generated in an electrically heated kiln at $1080^{\circ} \mathrm{C}$ using an existing thermal reduction process with 
duff coal as the reducing agent [15]. The sample was then stored in sealed plastic bags inside a container filled with nitrogen gas to ensure its stability and to avoid spontaneous oxidation to $\mathrm{CaSO}_{4}$ [18].

The elemental and mineralogical compositions of the gypsum waste sample, $\mathrm{CaS}_{\mathrm{r}}$ and the formed carbonate products were analysed using XRF (PANanalytical Axios X-ray fluorescence spectrometer equipped with a $4 \mathrm{~kW}$ Rh tube) and XRD (Bruker D8 Advance X-ray diffractometer), respectively. The samples were micronized to sub-30 $\mu \mathrm{m}$ particle size for increased accuracy prior to XRD analysis. The samples were further characterised for their total carbon and sulphur content using an Eltra CS800 Carbon \& Sulphur analyser (Eltra GmbH, Germany).

\subsection{Direct aqueous carbonation experiments}

Industrial-grade carbon dioxide $\left(\mathrm{CO}_{2}\right.$; Air Liquide, South Africa) was used in all carbonation experiments. The rationale for using $\mathrm{CO}_{2}$ in a direct carbonation setup was that i) it promotes $\mathrm{CaS}$ dissolution in water, ii) it induces the stripping of hydrogen sulphide gas $\left(\mathrm{H}_{2} \mathrm{~S}\right)$ from solution, and iii) it stimulates the carbonation of solubilized calcium derived from $\mathrm{CaS}$ dissolution to form calcium carbonate.

All experiments were performed in a 3-liter Perspex stirrer tank batch reactor equipped with four equally spaced baffles. The reactor was equipped with a sparger with small diameter $(<1 \mathrm{~mm})$ openings for the introduction of the $\mathrm{CO}_{2}$ gas. A mechanical overhead stirrer (RW 20 digital from IKA ${ }^{\circledR}$-Werke $\mathrm{GmbH}$ \& Co. KG, Germany) and a Rushton impeller (manufactured by Manten Engineering, South Africa) were used for mixing. The Rushton impeller had six vertical blades which are fixed onto a disk. This disk design ensured that most of the torque of the motor was consumed at the tips of the agitator. The $\mathrm{CO}_{2}$ gas flow rate was controlled using a rotameter (Fisher \& Porter, model 10A6132M/T62). All experiments were conducted at atmospheric pressure (Pretoria, South Africa).

$\mathrm{CaS}_{\mathrm{r}}$ was subjected to direct aqueous carbonation and stripping in a one-step process. A preliminary experiment was performed under set conditions to better understand the prevailing processes. For this purpose, $\mathrm{CaS}_{\mathrm{r}}$ was first dispersed in distilled water to obtain a $10 \mathrm{wt} \% \mathrm{CaS}_{\mathrm{r}}$ slurry. After $30 \mathrm{~min}$ of continuous mixing at $300 \mathrm{~min}^{-1}, \mathrm{CO}_{2}$ gas was introduced at a constant flow rate of $2.94 \mathrm{e} \mathrm{CO}_{2} / \mathrm{min} / \mathrm{kg} \mathrm{CaS}$ into the slurry. The $\mathrm{pH}$, electrical conductivity and temperature of the suspension were logged using a Hanna HI 2829 multiparameter logger at 5 second intervals to collect time-series data on the dynamics of the system. The reaction was terminated when the $\mathrm{pH}$ and electrical conductivity remained unchanged for 10 to $15 \mathrm{~min}$.

Upon completion, the suspension was removed from the reactor and filtered using Whatman grade no. 1 filter paper; the filter cake was thoroughly rinsed with water, dried at mild temperature (i.e $60^{\circ} \mathrm{C}$; to prevent thermal conversion of gypsum [19]) for $24 \mathrm{~h}$ and characterized by XRD and high-vacuum SEM. Throughout the experiments, sub-samples of the suspensions were collected from the reactor at regular intervals and filtered using $0.45 \mu \mathrm{m}$ PALL acrodisc PSF GxF/GHP membranes (Microsep (Pty) Ltd, South Africa). The filtrates were analysed for their calcium and sulphide content. Total sulphide concentration (sum of dissolved $\mathrm{H}_{2} \mathrm{~S}, \mathrm{HS}^{-}$and $\mathrm{S}^{2-}$ ) of the filtrates was determined iodometrically, where an excess of added iodine was titrated back with sodium 
thiosulfate. The analysis was carried out manually on filtered (for soluble sulphide) and unfiltered (for total sulphide, i.e. in both solution and solid phases) samples according to procedures $4500-\mathrm{S}^{2-}$ /lodometric method described in Standard Methods [20]. The sulphide in the solid phase and the sulphide stripped from solution were calculated by difference. The concentration of calcium ions in solution was determined by direct complexometric titration with ethylene-diamine tetraacetate (EDTA) according to the procedure 3500-Ca/EDTA titrimetric method [20]. High-vacuum scanning electron micrographs were collected using a JEOL JSM7500 microscope to obtain information on morphologies and size distribution of the solid materials. Samples were dispersed on carbon tape and sputter-coated with a thin, conductive layer of gold using a Emitech K950X sputter coater. The acceleration voltage was $2 \mathrm{kV}$.

The preliminary experiment was followed by a second set of experiments, where the effect of the stirring rate ( 180 vs 300 vs $480 \mathrm{~min}^{-1}$ ) on solution dynamics and the influence of the $\mathrm{CO}_{2}$ flow rate ( 2.53 vs 8.80 vs 14.83 vs 29.33 vs $44.00 \mathrm{e} \mathrm{CO} / \mathrm{min}$. $/ \mathrm{kg}$ calcine) on both solution dynamics and the $\mathrm{CaCO}_{3}$ particle characteristics were also studied.

\section{Results and Discussion}

\subsection{Materials characterization}

The XRD pattern of the untreated gypsum waste demonstrated that the primary mineral phase was gypsum $\left(\mathrm{CaSO}_{4} .2 \mathrm{H}_{2} \mathrm{O} ; 96.9 \%\right)$, which co-existed with magnesite $\left(\mathrm{MgCO}_{3} ; 3.1 \%\right)$. The amount of gypsum contained in the waste was further confirmed by the total content of calcium and sulphur determined by XRF (Table 1 ) and by carbon and sulphur analysis (Table 2) respectively. The sample

Table 1 Chemical composition (wt \%) of starting material and formed products.

\begin{tabular}{|c|c|c|c|c|c|c|c|c|}
\hline & & $\mathrm{SiO}_{2}$ & $\mathrm{Al}_{2} \mathrm{O}_{3}$ & $\mathrm{Fe}_{2} \mathrm{O}_{3(\mathrm{t})}$ & MgO & $\mathrm{CaO}$ & $\mathrm{SO}_{3}$ & $\mathrm{LOI}^{1}$ \\
\hline Untreated & gypsum & 0.13 & 0.08 & 0.03 & 0.27 & 30.18 & 47.71 & 21.59 \\
\hline wasteCaS $_{r}$ & & 4.07 & 2.58 & 0.90 & 0.07 & 50.84 & 60.41 & $-21.60^{2}$ \\
\hline Formed ca & & 3.21 & 2.14 & 1.17 & 0.02 & 40.01 & 5.92 & 44.73 \\
\hline
\end{tabular}

${ }^{1}$ Loss on ignition

${ }^{2}$ Sample $\mathrm{CaS}_{\mathrm{r}}$ exhibited a negative loss on ignition. This characteristic suggested the possible occurrence of a weight increase arising from the oxidation of $\mathrm{CaS}$ to $\mathrm{CaSO}_{4}$, which would have been higher than the weight loss caused by removing volatiles from the mineral structures. Similar observations were already made for ironrich coal ashes, in which case negative loss on ignition was best explained by the oxidation of $\mathrm{Fe}^{2+}$ to $\mathrm{Fe}^{3+}(\mathrm{FeO}$ to $\mathrm{Fe}_{2} \mathrm{O}_{3}$ ) and its associated weight increase [35]. 
Table 2 Carbon and sulphur content (wt \%) of starting material and formed products.

\begin{tabular}{lcc}
\hline & C & S \\
\hline Untreated gypsum waste & 0.29 & 18.17 \\
CaS $_{r}$ & & \\
Formed carbonate & 16.76 & 28.65 \\
& & \\
& 20.91 & 3.37 \\
\hline
\end{tabular}

was characterised by a mean diameter $D(v, 0.5)$ of $43.86 \mu \mathrm{m}$, with $90 \%$ of the particles being smaller than $176.70 \mu \mathrm{m}$. The gypsum waste was converted into $\mathrm{CaS}_{\mathrm{r}}$ by thermal reduction in an electrically heated kiln at $1080^{\circ} \mathrm{C}$, using duff coal as the reducing agent [15].

The bulk mineralogical composition of $\mathrm{CaS}_{\mathrm{r}}$ was also determined. The most abundant mineral was calcium sulphide ( $\mathrm{CaS} ; 50.7 \%$ ), also called oldhamite. Less abundant mineral phases included hydroxyapatite $\left(\mathrm{Ca}_{8.86}\left(\mathrm{PO}_{4}\right)_{6}\left(\mathrm{H}_{2} \mathrm{O}\right)_{2}\right)$, quartz $\left(\mathrm{SiO}_{2}\right)$, anhydrite $\left(\mathrm{CaSO}_{4}\right)$, and lime $(\mathrm{CaO})$. The sample contained $50.84 \% \mathrm{Ca}$ (Table 1 ) and $28.65 \%$ elemental sulphur (Table 2 ), which were present as both calcium sulphide and anhydrite (for $\mathrm{Ca}$ and $\mathrm{S}$ ), as well as hydroxyapatite (for $\mathrm{Ca}$ ). $\mathrm{CaS}_{\mathrm{r}}$ contained some impurities (e.g. Al, Fe; Table 1), which originated most probably from duff coal used during the thermal reduction process.

\subsection{Solution chemistry}

Theoretically, the direct reaction between solid $\mathrm{CaS}$ dispersed in water and $\mathrm{CO}_{2}$ produces $\mathrm{H}_{2} \mathrm{~S}$ gas and precipitated $\mathrm{CaCO}_{3}$ according to Eq. (5). The reaction involves at least four primary coexistent mechanisms: (i) aqueous dissolution of $\mathrm{CaS}$ and other soluble mineral phases, (ii) aqueous dissolution of $\mathrm{CO}_{2}$, (iii) precipitation of carbonates, and (iv) stripping of $\mathrm{H}_{2} \mathrm{~S}$.

$$
\mathrm{CaS}(\mathrm{s})+\mathrm{H}_{2} \mathrm{O}(\mathrm{l})+\mathrm{CO}_{2}(\mathrm{~g}) \rightarrow \mathrm{H}_{2} \mathrm{~S}(\mathrm{~g})+\mathrm{CaCO}_{3}(\mathrm{~s})
$$

The dynamics existing and evolving between these four mechanisms in the $\mathrm{CaS}-\mathrm{H}_{2} \mathrm{O}-\mathrm{CO}_{2}-\mathrm{H}_{2} \mathrm{~S}$ system was investigated by monitoring the profile of several solution parameters over time: conductivity and temperature (Figures $1 \mathrm{a}$ and $1 \mathrm{~b}$ respectively), and $\mathrm{pH}$ and the chemical distribution of sulphide species between solid, liquid and gaseous phases (Figure 2).

Preliminary experiment - Solid $\mathrm{CaS}_{\mathrm{r}}$ was initially suspended in water $\left(\mathrm{no} \mathrm{CO}_{2}\right)$ and was continuously mixed for $30 \mathrm{~min}$. Solution $\mathrm{pH}$ increased rapidly from 6.35 to 11.56 within the first minute, and stabilized at 11.71 after about 2 minutes of stirring. This was accompanied by an increase in solution conductivity $(c a .2 .5 \mathrm{~ms} / \mathrm{cm})$ and temperature $\left(\Delta \mathrm{T} 0.16^{\circ} \mathrm{C}\right)$, and in the concentration of soluble sulphur ( $9 \mathrm{mmol} / \mathrm{l}$ as S) and calcium $(9 \mathrm{mmol} / \mathrm{l}$ as $\mathrm{Ca}$ ); these observations could be ascribed to the dissolution of $\mathrm{CaS}$ present in $\mathrm{CaS}_{\mathrm{r}}$. The dissolution of anhydrite and hydroxyapatite cannot be discounted and may have contributed to the release of some calcium $\left(\mathrm{Ca}^{2+}\right)$ and sulphur $\left(\mathrm{S}^{2-}\right)$ in solution, although only to a small extent in comparison to CaS. CaS dissolution proceeded via the 
A.

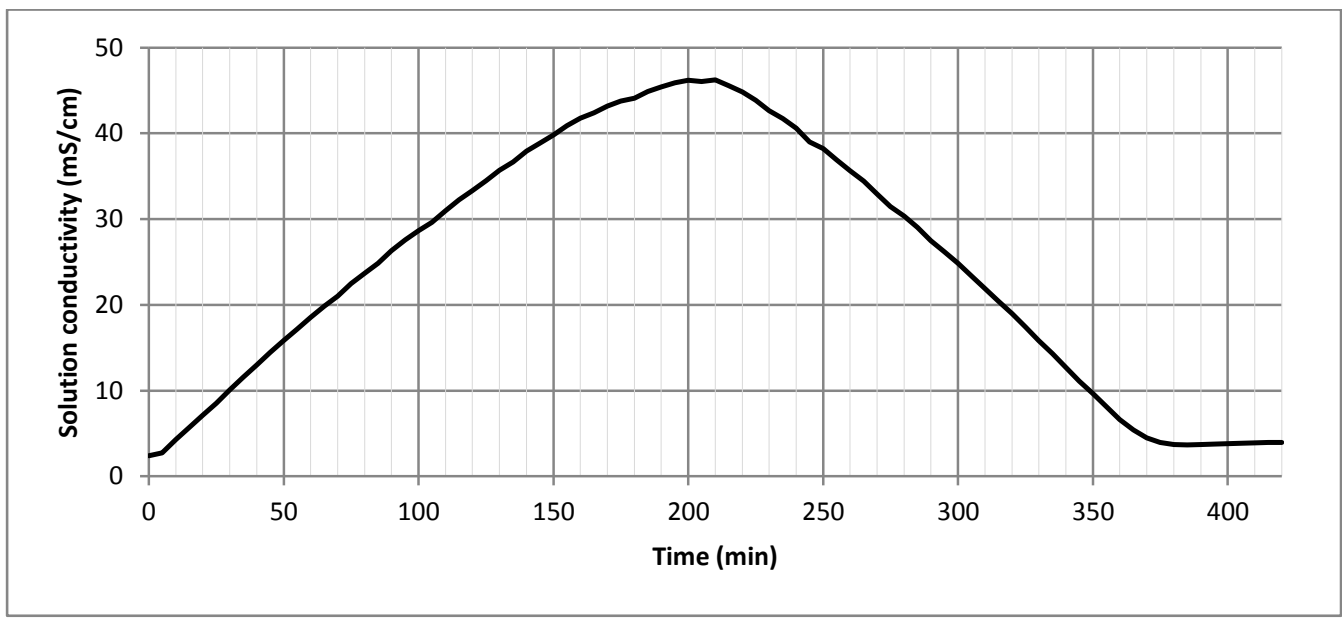

B.

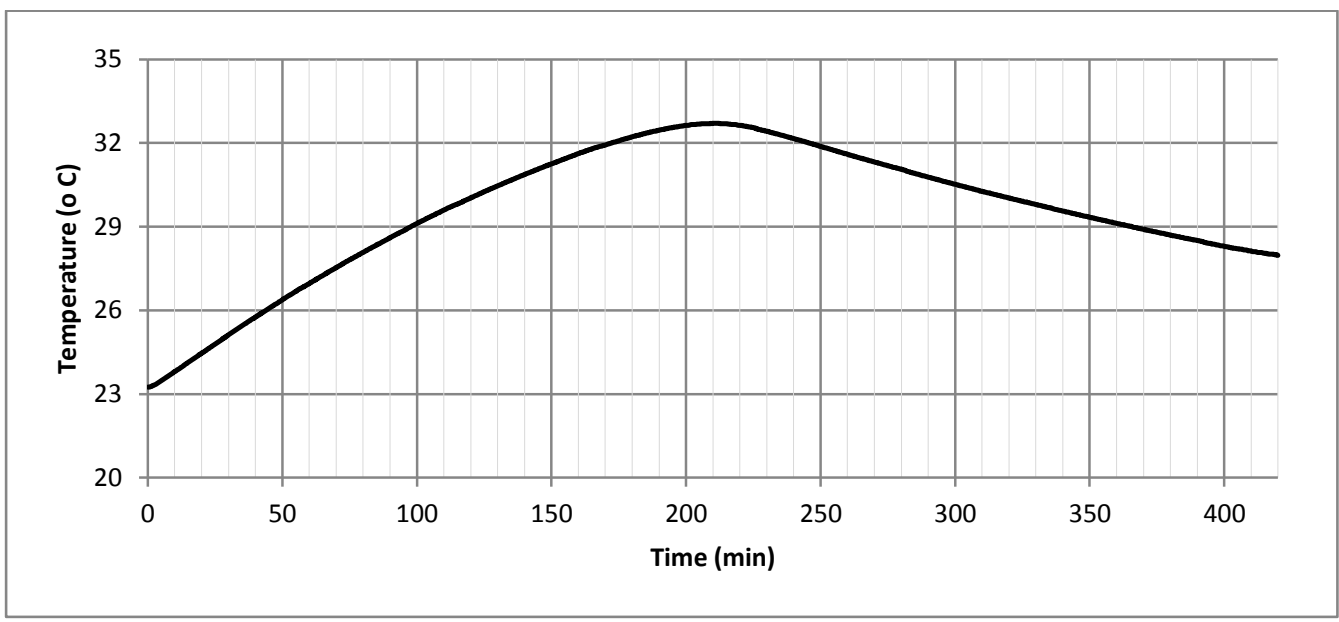

Figure 1 Solution conductivity (a) and temperature (b) profiles for the direct aqueous carbonation of the calcine sample suspended in distilled water (CaS slurry containing $22.7 \mathrm{~g}$ calcine/ $\mathrm{e}$; initial pH: 11.7; gas flow: $2.94 \mathrm{e} \mathrm{CO}_{2} / \mathrm{min} / \mathrm{kg}$ calcine; mixing rate: $180 \mathrm{~min}^{-1}$ ).

release of $\mathrm{Ca}^{2+}$ and $\mathrm{S}^{2-}$ ions in water, with $\mathrm{S}^{2-}$ subsequently binding with proton ions from the water molecules and thereby generating equimolar amounts of hydroxide ions $\left(\mathrm{OH}^{-}\right)$. As a result, a solution containing soluble calcium hydrosulfide $\left(\mathrm{Ca}(\mathrm{HS})_{2}\right)$ (Eq. (6); [21]), which was characterized by a $\mathrm{pH}$ of 11.71 (Figure 2), was generated. CaS is a sparingly soluble salt in water and reported values for its solubility at $25^{\circ} \mathrm{C}$ varies widely, with published values ranging from $0.125 \mathrm{~g} / \mathrm{l}$ to $1.0 \mathrm{~g} / \mathrm{l}$ [22-24]. The difference can be ascribed to the complicated dissolution mechanisms involved. The high sulphur content $(733 \mathrm{mmol} / \mathrm{l}$ as $\mathrm{S})$ of the solids dispersed in water and the low amount $(9 \mathrm{mmol} / \mathrm{l}$ as S) of dissolved $\mathrm{S}$ in solution measured following a period of $30 \mathrm{~min}$ of dissolution prior to the addition of $\mathrm{CO}_{2}$ (time $=0 \mathrm{~min}$ ) confirmed the low solubility of $\mathrm{CaS}$ in water (Figure 2).

$$
2 \mathrm{CaS}(\mathrm{s})+2 \mathrm{H}_{2} \mathrm{O}(\mathrm{l}) \leftrightarrow \mathrm{Ca}(\mathrm{HS})_{2}(\mathrm{aq})+\mathrm{Ca}(\mathrm{OH})_{2}(\mathrm{~s})
$$


Following the addition of $\mathrm{CO}_{2}$ to the aqueous $\mathrm{CaS}$ suspension, temporal changes in the conductivity and temperature of the solution were observed. They exhibited similarly-shaped profiles, with both

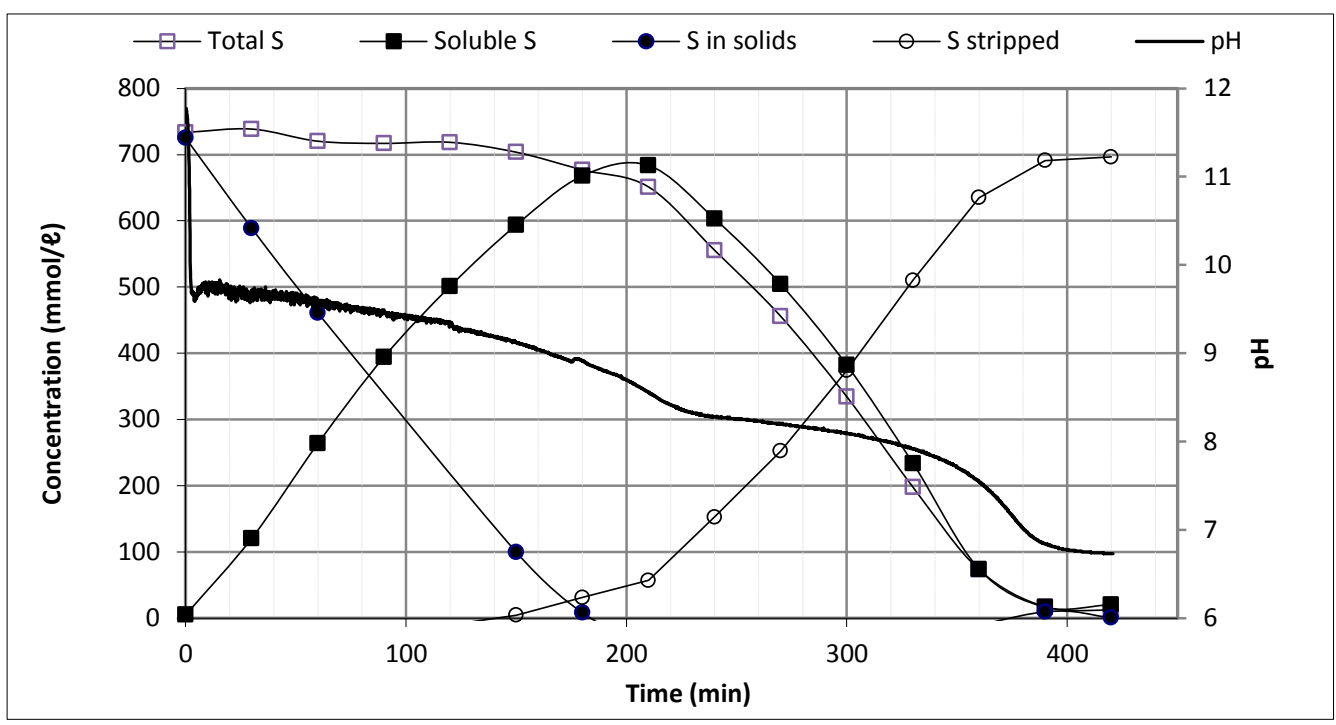

Figure 2 Changes in the chemical distribution of sulphide species between solid, liquid and gaseous phases during direct aqueous carbonation of the calcine sample (CaS slurry containing $22.7 \mathrm{~g}$

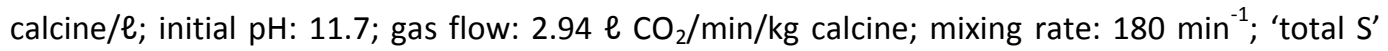
refers to total sulphur contained in the reactor, i.e. soluble sulphur + sulphur in solids).

parameters having reached their maxima after 200-210 min of reaction (Figure 1). These profiles correlated closely with the one found for the distribution of soluble sulphur species (Figure 2). When adding $\mathrm{CO}_{2}$ (time $=0 \mathrm{~min}$ ), the $\mathrm{pH}$ initially dropped sharply from 11.7 to 9.6 within a short period of time ( $<1 \mathrm{~min}$ ), after which it continued decreasing more gradually down to $c a$. 6.8 . The gradual drop in $\mathrm{pH}$ exhibited 3 different slopes: (1) from 1 to $125 \mathrm{~min}$, (2) from 125 to $210 \mathrm{~min}$, and (3) from 210 to $240 \mathrm{~min}$, before stabilizing at about 6.8 from $250 \mathrm{~min}$ onwards.

During the first stage of the reaction ( 0 to $200 \mathrm{~min}$ ), the total $\mathrm{S}$ concentration in the reactor remained constant at about $708 \mathrm{mmol} / \mathrm{l}$ (as S). The $\mathrm{S}$ concentration in solution increased steadily to a maximum of $684 \mathrm{mmol} / \mathrm{I}$ whilst the $S$ content in the undissolved material decreased at the same rate from about $730 \mathrm{mmol} / \mathrm{l}$ to about $8 \mathrm{mmol} / \mathrm{l}$. The steady increase in dissolved $\mathrm{S}$ upon $\mathrm{CO}_{2}$ addition, which was not observed in the absence of $\mathrm{CO}_{2}$, indicated the greater solubility of $\mathrm{CaS}$ in water in the presence of dissolved $\mathrm{CO}_{2}$. This was further confirmed by the increase in solution conductivity from 2.57 to $43.8 \mathrm{mS} / \mathrm{cm}$ during the first $120 \mathrm{~min}$. During this time, little, if any, $\mathrm{S}$ was stripped from the system (as indicated by the constant total $S$ concentration in the reactor), which can be explained by the hydrogen sulphide speciation diagram (Figure 3 ) illustrating the required $\mathrm{pH}$ conditions for $\mathrm{H}_{2} \mathrm{~S}$ formation. The diagram was obtained by calculating the fractional composition of the sulphide species in water using the dissociation constants for hydrogen sulphides at $25^{\circ} \mathrm{C}$. The ionization of $\mathrm{H}_{2} \mathrm{~S}$ in water proceeds in two steps and can be calculated from the dissociation constants $\left(K_{1}=9.1 \times 10^{-8}\right.$ and $\left.K_{2}=1.1 \times 10^{-12} ;[23]\right)$ and Eq. 7 and 8 .

$$
\begin{array}{ll}
\mathrm{H}_{2} \mathrm{~S}(\mathrm{aq})+\mathrm{H}_{2} \mathrm{O}(\mathrm{I}) \leftrightarrow \mathrm{HS}^{-}(\mathrm{aq})+\mathrm{H}_{3} \mathrm{O}^{+}(\mathrm{aq}) ; \mathrm{pKa}_{1}=7.04 \\
\mathrm{HS}^{-}(\mathrm{aq})+\mathrm{H}_{2} \mathrm{O}(\mathrm{I}) \leftrightarrow \mathrm{S}^{2-}(\mathrm{aq})+\mathrm{H}_{3} \mathrm{O}^{+}(\mathrm{aq}) ; & \mathrm{pKa}_{1}=11.96
\end{array}
$$




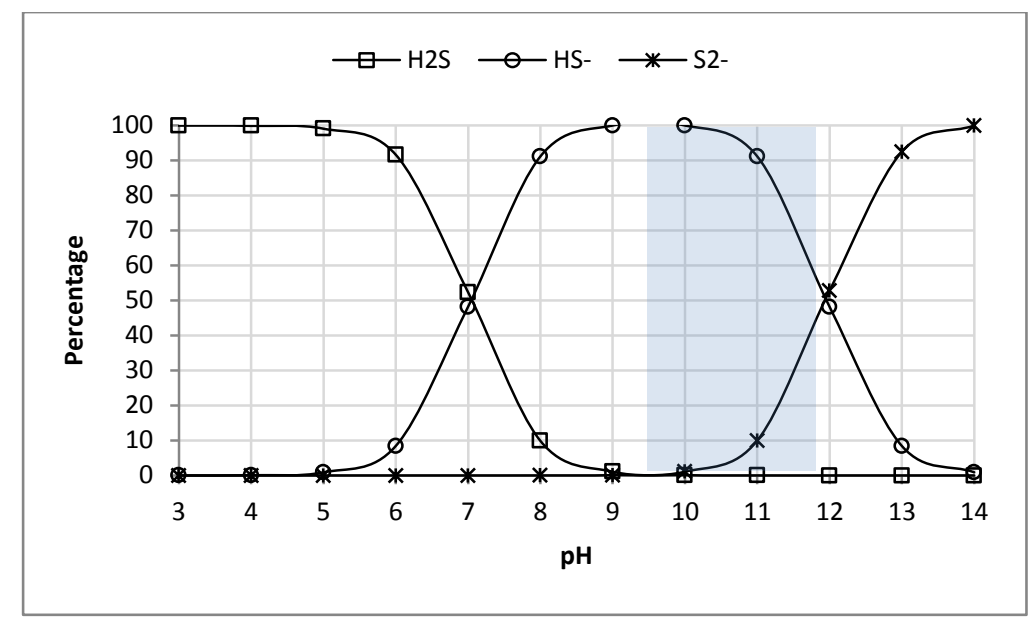

Figure 3 The hydrogen sulphide speciation diagram.

Temporal chemical analysis of the soluble sulphide and soluble calcium species (Figure 4 , time $=0$ to $120 \mathrm{~min}$ ) showed that one mole of $\mathrm{Ca}(\mathrm{HS})_{2}$ was formed for every two moles of CaS dissolved in the reactor, which is in agreement with Eq. (9).

$$
2 \mathrm{CaS}(\mathrm{s})+\mathrm{CO}_{2}(\mathrm{~g})+\mathrm{H}_{2} \mathrm{O}(\mathrm{aq}) \leftrightarrow \mathrm{Ca}(\mathrm{HS})_{2}(\mathrm{aq})+\mathrm{CaCO}_{3}(\mathrm{~s})
$$

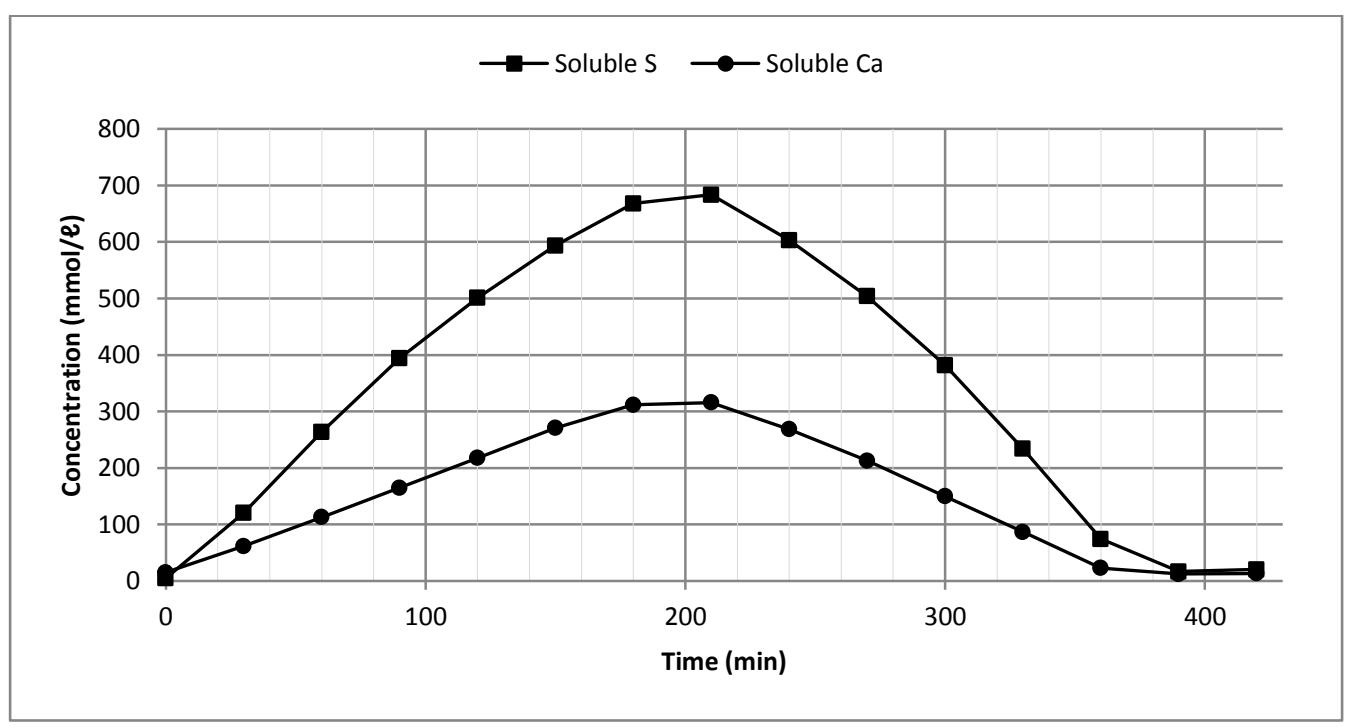

Figure 4 The distribution of soluble sulphide and soluble calcium concentrations with time of a calcine slurry in equilibrium with distilled water upon $\mathrm{CO}_{2}$ addition (CaS slurry containing $22.7 \mathrm{~g} / \mathrm{l}$ as S; initial pH: 11.7; gas flow: 2.94 I $\mathrm{CO}_{2} / \mathrm{min} . / \mathrm{kg}$ calcine; stirring rate: $180 \mathrm{~min}^{-1}$ ).

\subsection{Effect of stirring rate}

Solution dynamics - Figure 5 shows the effect of the stirring rate on $\mathrm{CaS}$ dissolution and $\mathrm{H}_{2} \mathrm{~S}$ stripping from the calcine slurry. During the first stage of the reaction, the electrical conductivity increased mainly as a result of $\mathrm{CO}_{2}$ gas absorption and $\mathrm{CaS}$ dissolution, and decreased in the second stage as a 


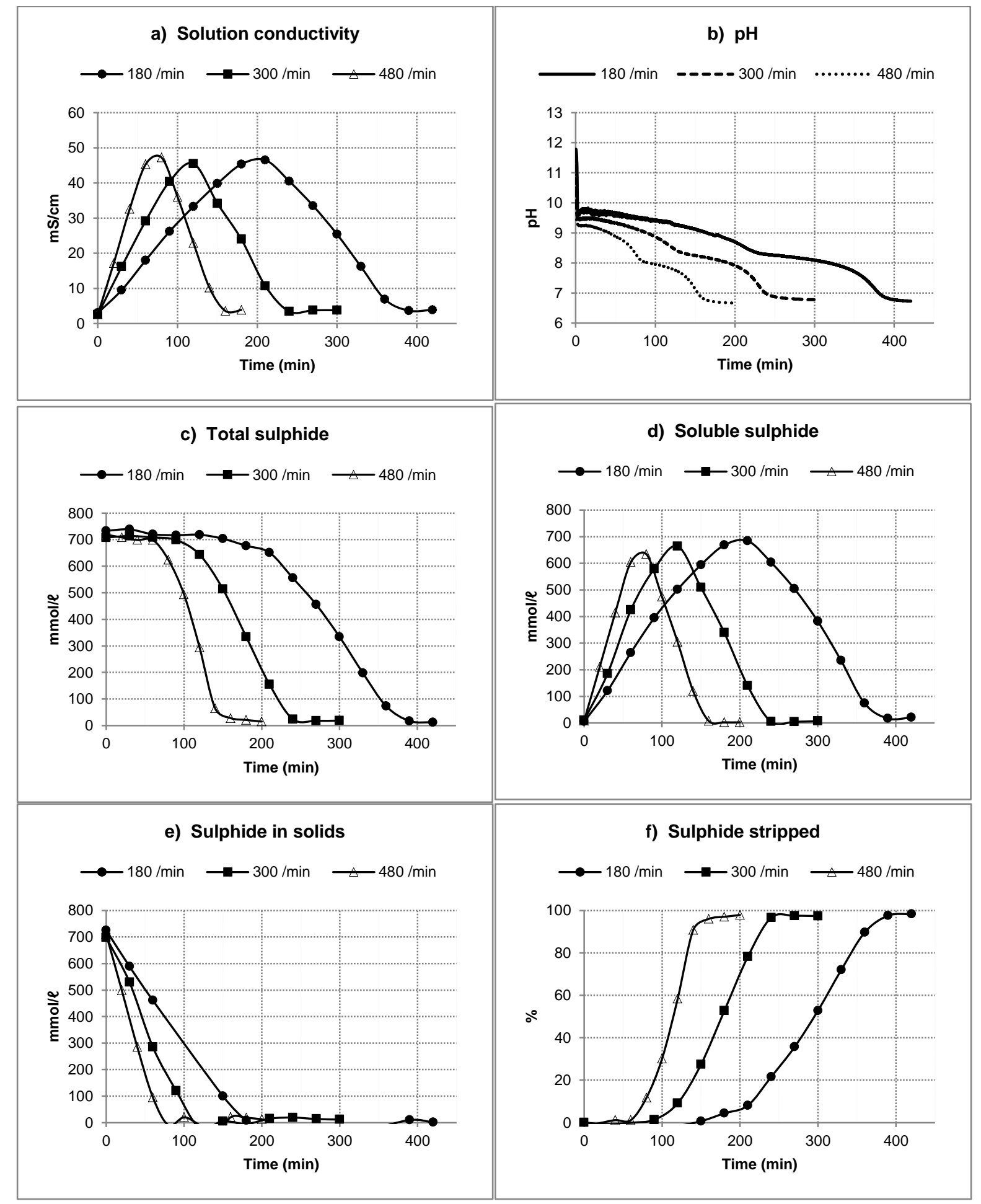

Figure 5 Effect of stirring rate on a) the solution conductivity, b) pH, c) total sulphide concentration, d) soluble sulphide concentration, e) sulphide in solid phase and f) sulphide stripped from solution with time (CaS slurry containing $22.7 \mathrm{~g} / \mathrm{e}$ as S; initial pH: 11.7 ; gas flow-rate: $2.94 \mathrm{e} \mathrm{CO}_{2} / \mathrm{min} / \mathrm{kg}$ calcine).

result of $\mathrm{H}_{2} \mathrm{~S}$ gas stripping and $\mathrm{CaCO}_{3}$ precipitation (Figure 5 (a)). With a stirring rate of $180 \mathrm{~min}^{-1}$ the reaction was complete (as indicated by levelling off of all the salient parameters) in approximately $390 \mathrm{~min}$, while the use of a stirring rate of $300 \mathrm{~min}^{-1}$ and $480 \mathrm{~min}^{-1}$ reduced the completion time of 
the reaction down to approximately $240 \mathrm{~min}$ and $160 \mathrm{~min}$, respectively. Both the rate of CaS dissolution and $\mathrm{H}_{2} \mathrm{~S}$ were positively influenced by faster stirring rates (Figure 5 (a)-(f)). The Rushton impeller used in this study was a radial flow type specially designed to provide high shear conditions required for breaking gas bubbles and thereby increasing the rate of gas transfer. In systems where mass transport is the rate-determining step, it is possible to increase the reaction rate by increasing the mass transfer rate [25]. For solid particles, the interfacial area is generally determined by the physical appearance of the particle and there is therefore little benefit in increasing the stirring rate. However, for gas reactions an increase in stirring rate can generate smaller bubbles and can consequently increase the interfacial area of $\mathrm{CO}_{2}$ gas bubbles. The increased interfacial area of the gas phase is directly related to an increase in the mass transfer rate [26]. The current experiments confirmed that faster reaction rates could be achieved by increasing stirring rates in the case of direct aqueous carbonation reactions. Table 4 illustrates that an increase in the stirring rate accelerated both the CaS dissolution reaction as well as the carbonation reaction.

\subsection{Effect of $\mathrm{CO}_{2}$ flow rate}

Solution dynamics - The effect of the $\mathrm{CO}_{2}$ gas flow rate on the temporal distribution of soluble sulphide concentrations was investigated. A summary of the calculated reaction rates for various $\mathrm{CO}_{2}$ flow rates is presented in Table 5. As shown in Figure 6, the reaction was complete (as indicated

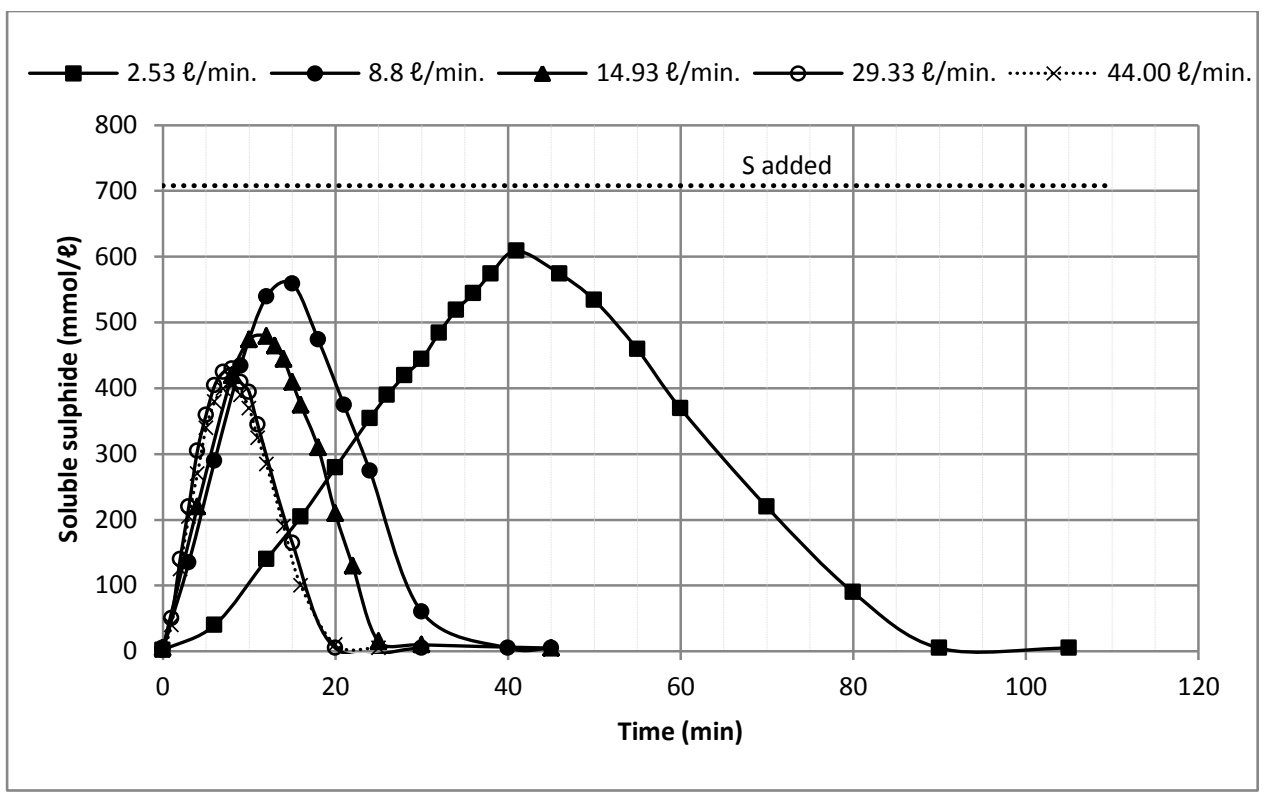

Figure 6 The effect of gas flow-rate $\left(\ell \mathrm{CO}_{2} / \mathrm{min} / \mathrm{kg}\right.$ calcine $)$ on the distribution of the soluble sulphide concentration with time (CaS slurry containing $22.7 \mathrm{~g} / \ell$ as S; initial $\mathrm{pH}$ : 11.7 ; stirring rate: 600 $\left.\min ^{-1}\right)$.

by the levelling off of soluble sulphide concentration) in approximately $86 \mathrm{~min}$ at a flow-rate of 2.53 $\ell \mathrm{CO}_{2} / \mathrm{min} / \mathrm{kg} \mathrm{CaS}$, while at 8.80, 14.93 and $29.33 \mathrm{e} \mathrm{CO}_{2} / \mathrm{min} / \mathrm{kg} \mathrm{CaS}$, the reactions were completed in 38,26 and $18 \mathrm{~min}$, respectively. The dissolution of gaseous $\mathrm{CO}_{2}$ in solution is generally the first rate-limiting step in direct carbonation reactions [27], but it can be enhanced by increasing the $\mathrm{CO}_{2}$ flow rate [28] when working at atmospheric pressure and thereby ensuring that excess carbonate ions are present relative to calcium ions. However, a further increase of the flow rate to more than $29.33 e \mathrm{CO}_{2} / \mathrm{min} / \mathrm{kg} \mathrm{CaS}$ had little effect on the overall reaction time (Table 5 and Figure 6). If the 
solubilisation of $\mathrm{CO}_{2}$ was the limiting factor, no further improvement in $\mathrm{CO}_{2}$ dissolution with increased flow rates would be evident due to the solubility of $\mathrm{CO}_{2}$, which is constant the given conditions. For example, at $25^{\circ} \mathrm{C}$ and 1 atmosphere, the solubility of $\mathrm{CO}_{2}$ is about $0.09 \mathrm{e} \mathrm{CO}_{2}$ per 100 $\mathrm{ml}$ of water [29]. When the $\mathrm{CO}_{2}$ gas flow rate is higher than the solubility of $\mathrm{CO}_{2}$ gas in water, the excess $\mathrm{CO}_{2}$ gas cannot be adsorbed and will run through the system, eventually escaping from solution in the gas phase. Under the specific experimental conditions, it is also possible that the dissolution of CaS might have been the rate-limiting step (not further investigated to confirm this mechanism). If solubilisation of calcium was slower than $\mathrm{CO}_{2}$ dissolution, the overall reaction time will also not increase upon increased $\mathrm{CO}_{2}$ flow rates.

It was also observed that the maximum sulphide concentration measured in solution was lower than that of total sulphide added to the system as $\mathrm{CaS}$ (i.e. $708 \mathrm{mmol} / \ell$ as $\mathrm{S}$ ) for all $\mathrm{CO}_{2}$ flow rates tested (Figure 6). Given that the sulphur content of all the carbonate products generated at different $\mathrm{CO}_{2}$ flow rates was very low $(<0.15$ mass \% (as $S))$, the loss of sulphur from the system could essentially be attributed to the escape of volatile $\mathrm{H}_{2} \mathrm{~S}$ gas.

$\mathrm{CaCO}_{3}$ produced - The effect of $\mathrm{CO}_{2}$ flow rate on the crystal structure and polymorphism of the formed $\mathrm{CaCO}_{3}$ products was also investigated. $\mathrm{CaCO}_{3}$ has three anhydrous crystalline forms (i.e. calcite, aragonite and vaterite). In this study, calcite and vaterite were the only polymorphs of $\mathrm{CaCO}_{3}$ that were identified, regardless of the $\mathrm{CO}_{2}$ flow rate used (Tables 3 and 6). The distribution of the

Table 3 Mineralogical composition (wt \%) of low-grade calcium carbonate formed, as determined by XRD using Rietveld refinement.

\begin{tabular}{|c|c|c|c|c|}
\hline Mineral & \multicolumn{2}{|r|}{ Chemical formula } & \multicolumn{2}{|c|}{$\begin{array}{c}\text { Low-grade } \mathrm{CaCO}_{3}{ }^{1} \\
\text { (wt \%) }\end{array}$} \\
\hline \multicolumn{2}{|l|}{ Calcite } & $\mathrm{CaCO}_{3}$ & \multicolumn{2}{|c|}{87.65} \\
\hline \multicolumn{2}{|l|}{ Vaterite } & $\mathrm{CaCO}_{3}$ & \multicolumn{2}{|c|}{0.59} \\
\hline Fluorite & \multicolumn{2}{|r|}{$\mathrm{CaF}_{2}$} & \multicolumn{2}{|c|}{1.22} \\
\hline Quartz & \multicolumn{2}{|r|}{$\mathrm{SiO}_{2}$} & \multicolumn{2}{|c|}{1.62} \\
\hline Apatite & \multicolumn{2}{|r|}{$\mathrm{Ca}_{5}\left(\mathrm{PO}_{4}\right)_{3} \mathrm{OH}$} & \multicolumn{2}{|c|}{3.46} \\
\hline Anhydrite & \multicolumn{2}{|r|}{$\mathrm{CaSO}_{4}$} & \multicolumn{2}{|c|}{5.40} \\
\hline Oldhamite & \multicolumn{2}{|r|}{$\mathrm{CaS}$} & \multicolumn{2}{|c|}{0.05} \\
\hline \multicolumn{5}{|c|}{$\begin{array}{l}{ }^{1} \mathrm{Low}_{\text {-grade }} \mathrm{CaCO}_{3} \text { is a published terminology [6] which refers to carbonate material containing }<90 \text { mass } \\
\text { as } \mathrm{CaCO}_{3} \text {. }\end{array}$} \\
\hline Stirring rate $\left(\min ^{-1}\right)$ & Process step & $\begin{array}{c}\text { Rate } \\
(\mathrm{g} / \mathrm{\ell} / \mathrm{min}(\text { as } \mathrm{S})) \\
\end{array}$ & $\begin{array}{c}\text { Standard deviation } \\
( \pm)\end{array}$ & $\mathbf{R}^{2}$ \\
\hline \multirow[t]{2}{*}{180} & CaS dissolution & 0.116 & 0.002 & \\
\hline & $\mathrm{H}_{2} \mathrm{~S}$ stripping & -0.127 & 0.002 & 0.9972 \\
\hline \multirow{2}{*}{300} & CaS dissolution & 0.218 & 0.005 & 0.9954 \\
\hline & $\mathrm{H}_{2} \mathrm{~S}$ stripping & -0.205 & 0.002 & 0.9993 \\
\hline \multirow{2}{*}{480} & CaS dissolution & 0.355 & 0.013 & 0.9948 \\
\hline & $\mathrm{H}_{2} \mathrm{~S}$ stripping & -0.313 & 0.005 & 0.9985 \\
\hline
\end{tabular}


combined $\mathrm{CaCO}_{3}$ phases reached $86-88$ mass \% (the sum of calcite and vaterite) in every sample produced, whilst mineral impurities (sum of all the non- $\mathrm{CaCO}_{3}$ mineral phases) amounted to 12-14 mass \%. $\mathrm{CaCO}_{3}$ discoloring could not be satisfactorily explained by the presence of the mineral impurities detected by XRD (Tables 3 and 6); it was probably due to ash from the duff coal used as reducing agent in the thermal reduction step, and possibly to a lesser extent to iron impurities $\left(1.17 \% \mathrm{Fe}_{2} \mathrm{O}_{3(t)} ;\right.$ Table 1). Based on their carbonate contents, the greyish products (Figure $\mathrm{S} 1$ )

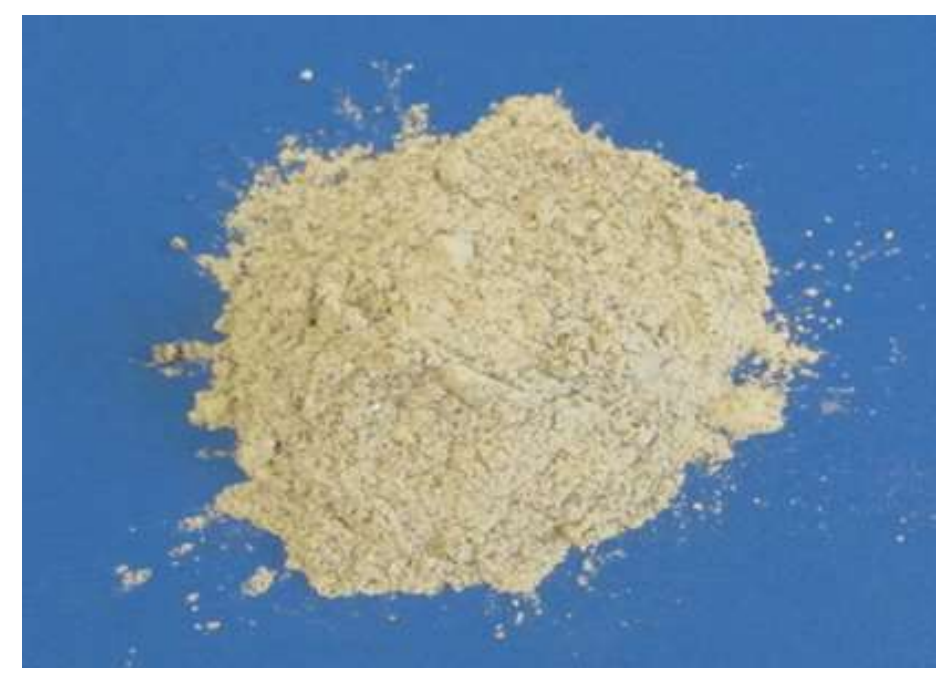

Supplementary Figure S1 Representative photograph of the low-grade $\mathrm{CaCO}_{3}$ product formed via the direct aqueous CaS process.

obtained were classified as low-grade $\mathrm{CaCO}_{3}\left(<90\right.$ mass $\%$ as $\left.\mathrm{CaCO}_{3} ;[6]\right)$. The XRD results showed that at the lowest $\mathrm{CO}_{2}$ flow rate of $2.5 \mathrm{e} \mathrm{CO}_{2} / \mathrm{min} / \mathrm{kg} \mathrm{CaS}$, the product was mainly composed of calcite. Samples prepared at higher $\mathrm{CO}_{2}$ flow rates showed the presence of binary mixtures of calcite and vaterite, with a progressive decrease in mole fraction of calcite and a corresponding increase of vaterite with increased $\mathrm{CO}_{2}$ flow rates. Figure 7 depicts a clearer view on the variation in the proportion of calcite to vaterite produced at different $\mathrm{CO}_{2}$ flow rates. Therefore, although the total $\mathrm{CaCO}_{3}$ content of produced lowgrade $\mathrm{CaCO}_{3}$ was not significantly different between the $\mathrm{CO}_{2}$ flow rates tested, the distribution ratio of calcite and vaterite was greatly influenced by the $\mathrm{CO}_{2}$ flow rate. For all flow rates tested, the conversion of CaS was complete, with only trace amounts $(<0.1 \%)$ of CaS detected in the produced materials. 


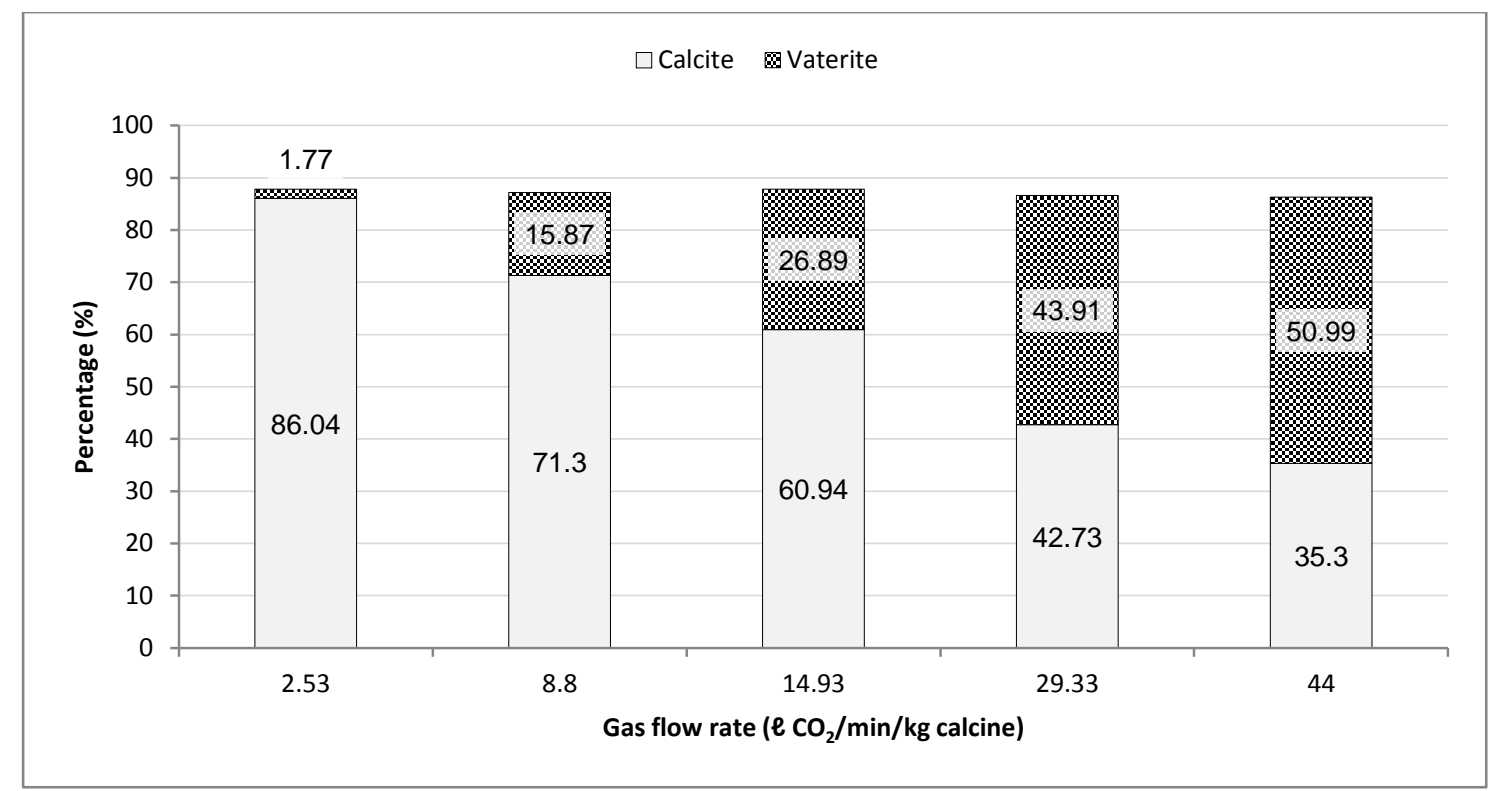

Figure 7 The distribution ratio of calcite and vaterite polymorphs in the low-grade $\mathrm{CaCO}_{3}$ products formed at various $\mathrm{CO}_{2}$ gas flow rates (CaS slurry containing $22.7 \mathrm{~g} / \mathrm{e}$ as $\mathrm{S}$; initial $\mathrm{pH}$ : 11.7; stirring rate: $\left.600 \mathrm{~min}^{-1}\right)$.

Table 5 Effect of the $\mathrm{CO}_{2}$ flow rate on reaction rate (CaS slurry containing $22.7 \mathrm{~g} \mathrm{~S} / \ell$; initial pH: 11.7 ; stirring rate: $600 \mathrm{~min}^{-1}$ ).

\begin{tabular}{|c|c|c|c|c|c|c|c|}
\hline \multirow{2}{*}{$\begin{array}{l}\mathrm{CO}_{2} \text { flow } \\
(\ell / \mathrm{min} / \mathrm{kg} \\
\text { calcine })\end{array}$} & \multirow[b]{2}{*}{ Process step } & \multicolumn{3}{|c|}{ Reaction kinetics } & \multirow{2}{*}{$\begin{array}{l}\text { Reaction } \\
\text { time } \\
\text { (min) }\end{array}$} & \multicolumn{2}{|c|}{ Actual } \\
\hline & & $\begin{array}{c}\text { Rate } \\
\text { (mmol/e/min } \\
\text { (as S)) }\end{array}$ & $\begin{array}{c}\text { Standard } \\
\text { deviation } \\
( \pm)\end{array}$ & $\mathbf{R}^{2}$ & & $\begin{array}{c}\text { Actual } \\
\text { (g/100g } \\
\left.\text { CaS }_{\mathrm{r}}\right)\end{array}$ & $\%$ yield \\
\hline \multirow[t]{2}{*}{2.53} & CaS dissolution & 16.08 & 0.43 & 0.9929 & \multirow[t]{2}{*}{86} & \multirow[t]{2}{*}{127.3} & \multirow[t]{2}{*}{$91.7 \%$} \\
\hline & $\mathrm{H}_{2} \mathrm{~S}$ stripping & -13.57 & 0.57 & 0.9913 & & & \\
\hline \multirow[t]{2}{*}{8.80} & CaS dissolution & 45.57 & 1.58 & 0.9964 & \multirow[t]{2}{*}{38} & \multirow[t]{2}{*}{127.5} & \multirow[t]{2}{*}{$91.9 \%$} \\
\hline & $\mathrm{H}_{2} \mathrm{~S}$ stripping & -21.82 & 4.36 & 0.8931 & & & \\
\hline \multirow[t]{2}{*}{14.93} & CaS dissolution & 47.87 & 3.06 & 0.9919 & \multirow[t]{2}{*}{26} & \multirow[t]{2}{*}{126.5} & \multirow[t]{2}{*}{$91.2 \%$} \\
\hline & $\mathrm{H}_{2} \mathrm{~S}$ stripping & -30.76 & 2.93 & 0.9402 & & & \\
\hline \multirow[t]{2}{*}{29.33} & CaS dissolution & 65.12 & 4.16 & 0.9761 & \multirow[t]{2}{*}{18} & \multirow[t]{2}{*}{128.1} & \multirow[t]{2}{*}{$92.3 \%$} \\
\hline & $\mathrm{H}_{2} \mathrm{~S}$ stripping & -38.34 & 1.92 & 0.9925 & & & \\
\hline \multirow{2}{*}{44.00} & CaS dissolution & 61.81 & 3.65 & 0.9795 & \multirow{2}{*}{18} & \multirow[t]{2}{*}{130.6} & \multirow{2}{*}{$94.1 \%$} \\
\hline & $\mathrm{H}_{2} \mathrm{~S}$ stripping & -36.88 & 2.27 & 0.9814 & & & \\
\hline
\end{tabular}


Table 6 Mineralogical composition of low-grade $\mathrm{CaCO}_{3}$ produced at different $\mathrm{CO}_{2}$ gas flow rates (CaS slurry containing $22.7 \mathrm{~g} / \mathrm{\ell}$ as S; initial $\mathrm{pH}: 11.7$; stirring rate: $600 \mathrm{~min}^{-1}$ ).

\begin{tabular}{lccccc}
\hline $\begin{array}{c}\text { Mineral composition } \\
(\text { mass \%)* }\end{array}$ & $\mathbf{2 . 5}$ & $\mathbf{8 . 8}$ & $\mathbf{1 4 . 9}$ & $\mathbf{2 9 . 3}$ & $\mathbf{4 4 . 0}$ \\
\hline Calcite & 86.0 & 71.3 & 60.9 & 42.7 & 35.3 \\
Anhydrite & 4.5 & 3.4 & 3.2 & 3.1 & 3.6 \\
Vaterite & 1.8 & 15.9 & 25.9 & 43.9 & 51.0 \\
Quartz & 1.9 & 3.0 & 2.0 & 2.5 & 2.5 \\
Apatite & 4.1 & 4.7 & 5.1 & 5.7 & 5.6 \\
Fluorite & 1.4 & 1.2 & 1.3 & 1.3 & 1.1 \\
\hline
\end{tabular}

* Only minerals present in amounts larger than $1 \%$ are reported.
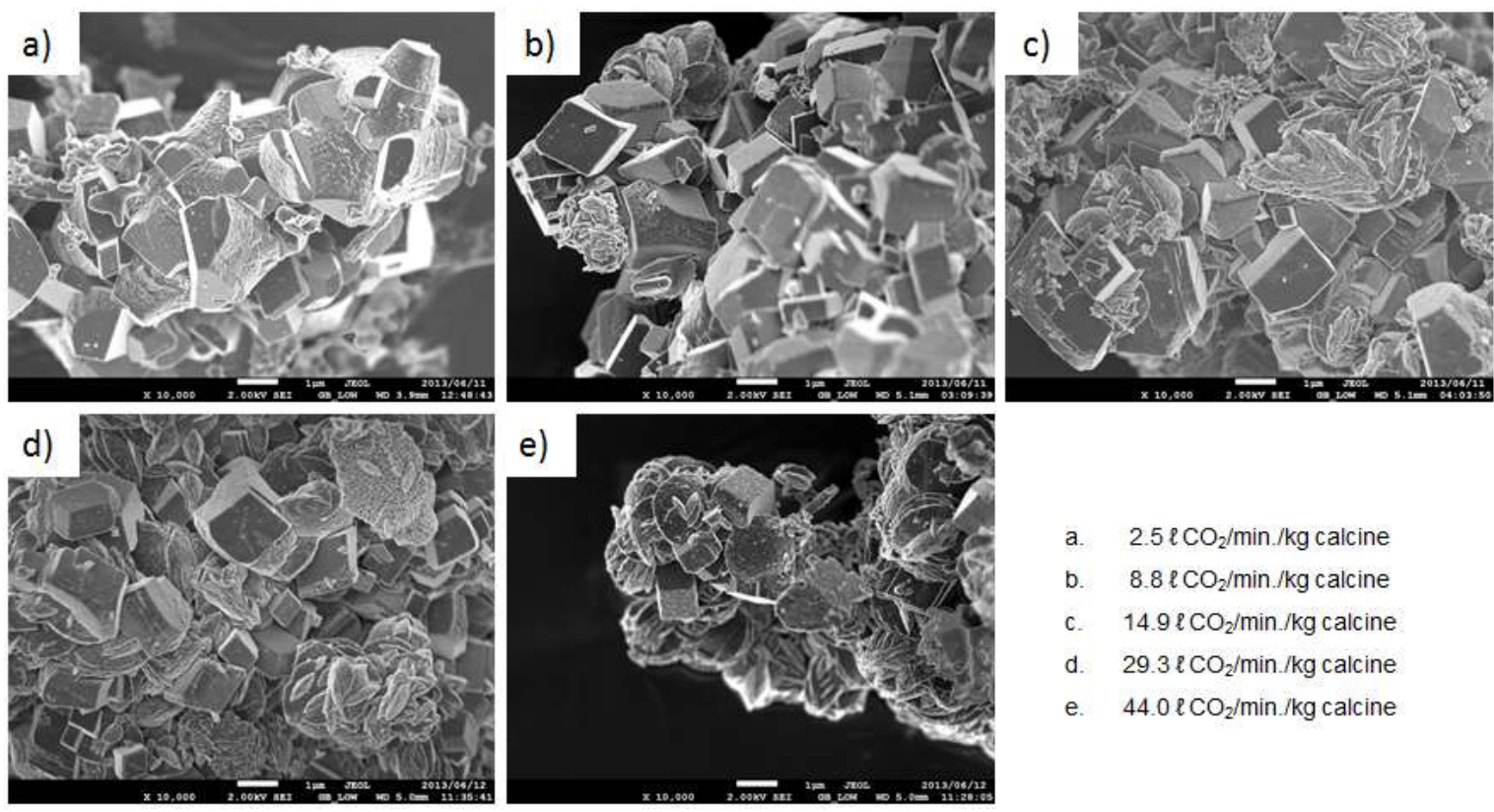

Figure 8 Low-magnification SEM micrographs of low-grade $\mathrm{CaCO}_{3}$ products formed at various $\mathrm{CO}_{2}$ gas flow rates (CaS slurry containing $22.7 \mathrm{~g} / \mathrm{\ell}$ as S; initial $\mathrm{pH}$ : 11.7; stirring rate: $600 \mathrm{~min}^{-1}$ ).

SEM micrographs of the samples produced at different $\mathrm{CO}_{2}$ flow rates confirmed the distribution between the two polymorphs identified by XRD (Figure 8). The two prevalent $\mathrm{CaCO}_{3}$ phases can clearly be distinguished by their characteristic morphologies. Vaterite can be recognised as the lensshaped particles [30] whilst calcite was identified as rhombohedral crystallites [31]. All precipitates were micron-sized lumps made up of randomly aggregated rhombohedra of calcite and lens-shaped (or ellipse-like) vaterite. The product generated at $2.5 \mathrm{e} \mathrm{CO}_{2} / \mathrm{min} / \mathrm{kg} \mathrm{CaS}$ consisted mostly of irregular polyhedron calcite crystals (Figure 8a). Some crystal planes of the irregular polyhedron structure were flat with smooth surfaces, while other planes were rough with a "step" structure. At higher $\mathrm{CO}_{2}$ flow rates, mixtures of vaterite and calcite were found (Figures $8 \mathrm{~b}-\mathrm{e}$ ). Interpenetrated rhombohedral cubes of calcite with smooth surfaces and mixtures of ragged and sharp edges were 
identified. Calcite particles aggregated to form large, irregular particles and were partly overgrown by clusters of vaterite (Figures $8 \mathrm{~b}-\mathrm{e}$ ). It was also observed that only lens-shape vaterite particles had been formed in this study, and no classical spherical vaterite particles had been identified. Figure $9 a$ shows a higher magnification of Figure $8 \mathrm{c}$, whilst Figure $9 \mathrm{~b}$ exhibits a higher magnification of Figure 8 e to illustrate the detail of the lens-shape vaterite crystals.
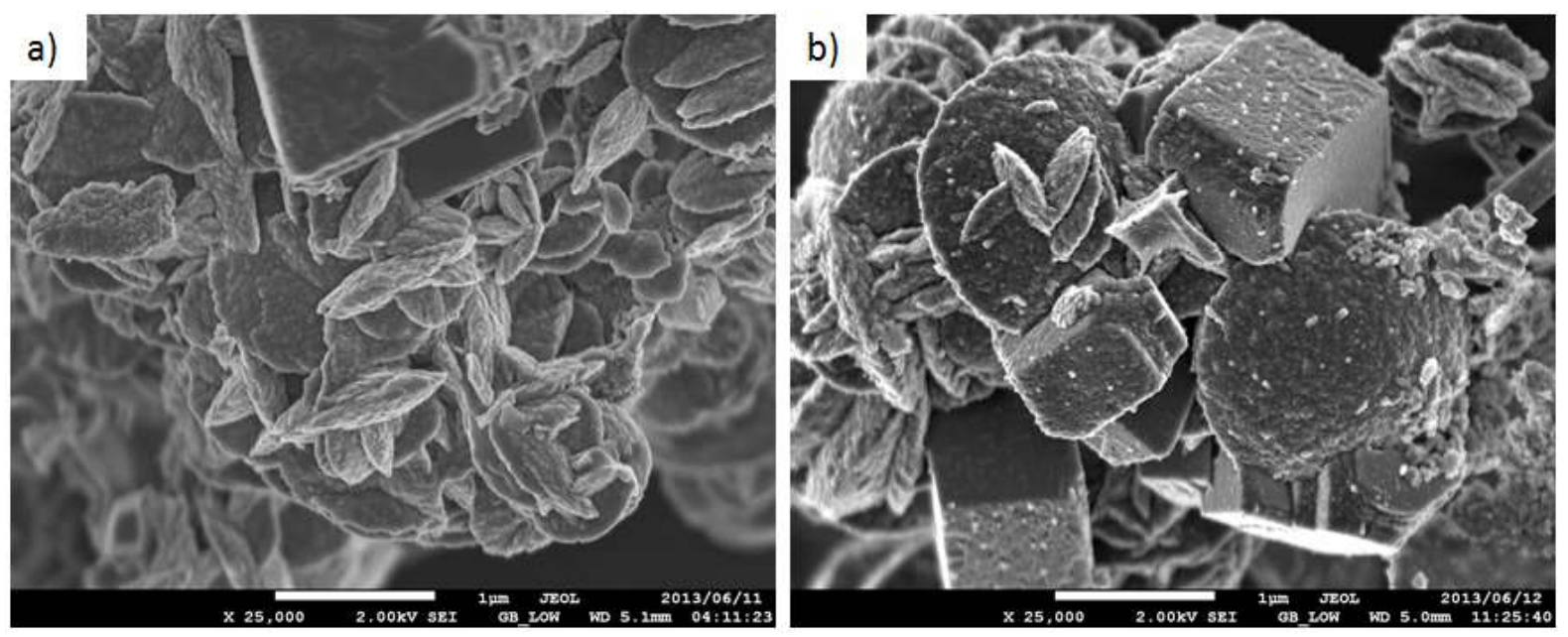

Figure 9 SEM micrographs of low-grade $\mathrm{CaCO}_{3}$ products at $25000 \times$ magnification showing the lensshaped crystals of vaterite produced at a) 14.5 and b) $44.0 \ell \mathrm{CO}_{2} / \mathrm{min} / \mathrm{kg}$ calcine respectively (CaS slurry containing $22.7 \mathrm{~g} / \mathrm{l}$ as S; initial $\mathrm{pH}: 11.7$; stirring rate: $600 \mathrm{~min}^{-1}$ ).

The median size $\mathrm{D}(\mathrm{v}, 0.5)$ of the particles produced at $\mathrm{CO}_{2}$ flow rates between 2.53 and $44.00 \mathrm{l} / \mathrm{min} / \mathrm{kg}$ calcine varied between 16.1 and $21.3 \mu \mathrm{m}$. No significant reduction in median particle sizes was observed when using higher $\mathrm{CO}_{2}$ flow rates, which was in agreement with published findings [32]. Approximately $0.95 \mathrm{~kg}$ low-grade $\mathrm{CaCO}_{3}\left(<90\right.$ mass\% as $\left.\mathrm{CaCO}_{3}\right)$ was produced for every $1 \mathrm{~kg}$ of $\mathrm{CaS}_{\mathrm{r}}$ processed. Actual yields were independent of the $\mathrm{CO}_{2}$ flow rate.

\subsection{Estimated economic feasibility}

On the basis of our laboratory studies, the recovery of $\mathrm{CaCO}_{3}$ and sulphur ( $\mathrm{S}$ recovery studies not included in this paper) from gypsum waste is economically promising. The treatment of 1 ton of waste gypsum yields 0.58 ton of $\mathrm{CaCO}_{3}$ (valued at R145) and 0.19 ton of sulphur (valued at R294). The price of $\mathrm{CaCO}_{3}$ and sulphur were taken as $\mathrm{R} 250 / \mathrm{t}$ and $\mathrm{R} 1550 / \mathrm{t}$ respectively (average values from 2007 to 2011, for limestone sales in South Africa and S imports to South Africa [33]). This compares favourably with the input cost of the main raw material, coal. 0.14 ton of coal is needed for the thermal reduction of 1 ton of waste gypsum to CaS. At a coal cost of R400/t, the input cost of the coal amounts to R56/t waste gypsum. This is significantly less than the combined value of the products, $\mathrm{R} 383$ for $\mathrm{CaCO}_{3}$ and sulphur (the energy requirement of the thermal process was not taken into account). The major advantage of the process of conversion of gypsum waste to commercialgrade products lies in the savings on gypsum waste disposal costs. Long-term storage and management of gypsum waste dumps present economic as well as potential environmental challenges. Not only are these dumps unsightly, but they also occupy large areas of land and require long-term expenditures for maintenance and monitoring. 


\section{Conclusions}

The production of elemental sulphur and $\mathrm{CaCO}_{3}$ from gypsum waste can be successfully achieved by combining the thermal reduction of gypsum into calcium sulphide (CaS), followed by the direct aqueous carbonation of $\mathrm{CaS}$ for the generation of hydrogen sulphide $\left(\mathrm{H}_{2} \mathrm{~S}\right)$ and $\mathrm{CaCO}_{3}$, and the subsequent conversion of $\mathrm{H}_{2} \mathrm{~S}$ into $\mathrm{S}$ via the commercially available chemical catalytic Clauss process. While the overall process can successfully produce elemental sulphur, this study has shown that direct carbonation can only yield low-grade $\mathrm{CaCO}_{3}$ products (i.e. $<90$ mass $\%$ as $\mathrm{CaCO}_{3}$ ), which are made up of binary mixtures of calcite and vaterite, with a progressive decrease in mole fraction of calcite and corresponding increase of vaterite with increased $\mathrm{CO}_{2}$ flow rates. These formed materials could replace the Sappi Enstra $\mathrm{CaCO}_{3}$ (69 mass \% $\mathrm{CaCO}_{3}$ ), a by-product from the paper industry which is used in many full-scale AMD neutralisation plants in South Africa [34] but is becoming insufficient. The insight gained on the solution chemistry and the characteristics of formed $\mathrm{CaCO}_{3}$ derived from this study on the direct aqueous CaS carbonation process has also served as the basis for our current effort in developing and optimising indirect aqueous $\mathrm{CaS}$ carbonation processes for the production of high-grade $\mathrm{CaCO}_{3}$ (i.e. $>99$ mass $\%$ as $\mathrm{CaCO}_{3}$ ) or precipitated calcium carbonate (PCC).

\section{Acknowledgments}

The authors thank the following organisations for financial support and/or technical/scientific input: THRIP (Technology and Human Resource for Industry Programme of the National Research Foundation (NRF)), Tshwane University of Technology (TUT), North-West University (NWU), the Council for Scientific and Industrial Research (CSIR) and the Council for Geoscience (CGS).

\section{References}

[1] F. Macías, M.A. Caraballo, J.M. Nieto, Environmental assessment and management of metal-rich wastes generated in acid mine drainage passive remediation systems, J. Hazard. Mater. 229-230 (2012) 107-114.

[2] D. Tao, S. Chen, B.K. Parekh, M.T. Hepworth, An investigation of a thermochemical process for conversion of gypsum and pyrite wastes into useful products, Adv. Environ. Res. 5 (2001) 277-284.

[3] N.R. Nengovhela, C.A. Strydom, J.P. Maree, S. Oosthuizen, D.J. Theron, Recovery of sulphur and calcium carbonate from waste gypsum, Water SA 33 (2007) 741-747.

[4] D.J. Cork, D.E. Jerger, A. Maka, Biocatalytic production of sulphur from process waste streams, Biotechnol. Bioeng. 16 (1986) 149-162.

[5] D.J. Cork, D.E. Jerger, A. Maka, Biocatalytic production of sulphur from process waste streams, Biotechnol. Bioeng. 16 (1986) 149-162.

[6] J.A.H. Oates, Lime and limestone: Chemistry and technology, production and uses. Wiley-VCH Verlag $\mathrm{GmbH}$, Weinheim, 1998.

[7] M. Windholz, The Merck Index, tenth ed., Merck \& Co., Inc., New Jersey, 1983. 
[8] W. Zhang, X. Li, Z. Qu, Q. Zhao, G. Chen, Facile solution synthesis and characterization of $\mathrm{CaCO}_{3}$ microspheres with urchin-shaped structure, Mater. Lett. 64 (2010) 71-73.

[9] L. Ma, X. Niu, J. Hou, S. Zheng, W. Xu, Reaction mechanism and influence factors analysis for calcium sulfide generation in the process of phosphogypsum decomposition, Thermochim. Acta 526 (2011) 163-168.

[10] T. Kato, K. Murakami, K. Sugawara, Carbon reduction of gypsum produced from flue gas desulfurization, Chem. Eng. Trans. 29 (2012) 805-810.

[11] Z. Miao, H. Yang, Y. Wu, H. Zhang, X. Zhang, Experimental studies on decomposing properties of desulfurization gypsum in a thermogravimetric analyzer and multi-atmosphere fluidized beds, Ind. Eng. Chem. Res. 51 (2012) 5419-5423.

[12] X. Zhang, X. Song, Z. Sun, P. Li, J. Yu, (2012) Density functional theory study on the mechanism of calcium sulfate reductive decomposition by carbon monoxide, Ind. Eng. Chem. Res. 51 (2012) 6563-6570.

[13] P. Ning, S.C. Zheng, L.P. Ma, Y.L. Du, W. Zhang, X.K. Niu, F.Y. Wang, Kinetics and thermodynamics studies on the decomposition of phosphogypsum in different atmospheres, Adv. Mater. Res. 160-162 (2011) 842-848.

[14] H.F. Mark, D.F. Othtmer, C.G. Overberger, G.T. Seaborg, Kirk-Othmer: Encyclopedia of Chemical Technology, third ed., Wiley-Interscience, New York, 1978.

[15] S. Ruto, J.P. Maree, C.M. Zvinowanda, W.J. Louw, A.V. Kolesnikov, (2011) Thermal studies on gypsum in a pilot-scale rotary kiln, Water in the South African Minerals Industry Conference Proceedings, 15-17 February 2011, The Southern African Institute of Mining and Metallurgy, 2011.

[16] H. Selim, A.K. Gupta, A. Al Shoaibi, Effect of reaction parameters on the quality of captured sulphur in Claus process, Appl. Energy 104 (2013) 772-776.

[17] M.W. Brooks, S. Lynn, Recovery of calcium carbonate and hydrogen sulfide from waste calcium sulphide, Ind. Eng. Chem. Res. 36 (1997) 4236-4242.

[18] M. Garcia-Calzada, G. Marban, A.B. Fuertes, Decomposition of CaS particles at ambient conditions, Chem. Eng. Sci. 55 (2000) 1661-1674.

[19] P. Ballirano, E. Melis, Thermal behaviour and kinetics of dehydration of gypsum in air from in situ real-time laboratory parallel-beam X-ray powder diffraction, Phys. Chem. Minerals 36 (2009) 391-402.

[20] L.S. Clesceri, A.E. Greenberg, R.R. Trussel, Standard Methods for the Examination of Water and Wastewater, seventeeth ed., American Public Health Association, Washington, 1989.

[21] I. Zekker, T. Tenno, A. Selberg, K. Uiga, Dissolution modelling and experimental measurement of $\mathrm{CaS}-\mathrm{H}_{2} \mathrm{O}$ binary system, Chin. J. Chem. 29 (2011) 2327-2336. 
[22] R.C. Weast, CRC Handbook of Chemistry and Physics, fifty-third ed., The Chemical Rubber Co., Cleveland, 1972.

[23] R.H. Perry, Green D., Perry's Chemical Engineers' Handbook, sixth ed. McGraw-Hill Book Company, New York, 1984.

[24] J.A. Dean, Lange's Handbook of Chemistry, fourteenth ed., McGraw-Hill, New York, 1992.

[25] R. Sardeing, J. Aubin, M. Poux, C. Xuereb, Gas-Liquid mass transfer - Influence of sparger location, Chem. Eng. Res. and Des. 82 (2004) 1161-1168.

[26] M. Martin, F.J. Montes, M.A. Galan, Bubbling process in stirred tank reactors II: Agitator effect on the mass transfer rates, Chem. Eng. Sci. 63 (2008) 3223-3234.

[27] S.K. Jana, A.N. Bhaskarwar, Gas absorption accompanied by chemical reaction in a system of three-phase slurry-foam reactors in series, Chem. Eng. Res. and Des. 89 (2011) 793-810.

[28] P.C. Chen, W. Shi, R. Du, V. Chen, Scrubbing of $\mathrm{CO}_{2}$ greenhouse gases, accompanied by precipitation in a continuous bubble-column scrubber, Ind. Eng. Chem. Res. 47 (2008) 6336-6343.

[29] V.A. Juvekar, M.M. Sharma, Absorption of $\mathrm{CO}_{2}$ in a suspension of lime, Chem. Eng. Sci. 28 (1977) 825-837.

[30] N. Gehrke, H. Cölfen, N. Pinna, M. Antonietti, N. Nassif, Superstructures of calcium carbonate crystals by oriented attachment, Cryst. Growth Des. 5 (2005) 1317-1319.

[31] A.R. Ibrahim, J.B. Vuningoma, X. Hu, Y. Gong, D. Hua, Y. Hong, H. Wang, J. Li, High-pressure gassolid carbonation route coupled with a solid ionic liquid for rapid synthesis of rhombohedral calcite, J. Supercrit. Fluids 72 (2012) 78-83.

[32] B. Feng, A.K. Yong, H. An, Effect of various factors on the particle size of calcium carbonate formed in a precipitation process, Mater. Sci. Eng. A 445-446 (2007) 170-179.

[33] I.Robinson, M. Mabuza, S. Mohale, P. Mwape, N. Dlambulo, L. Malebo, M. Ikaneng, R. Motsie, M. Bonga, M. Köhler (Eds), South Africa's Mineral Industry 2011/2012, Department of Mineral Resources, Pretoria, South Africa (2012) pp. 216.

[34] S. Motaung, J. Maree, M. De Beer, L. Bologo, D. Theron, J. Baloyi, Recovery of drinking water and by-products from gold mine effluents, Int. J. Water Res. Dev. 24 (2008) 433-450.

[35] R.E. Vandenberghe, V.G. de Resende, G.M. da Costa, E. De Grave, Study of loss-on-ignition anomalies found in ashes from combustion of iron-rich coal, Fuel 89 (2010) 2405-2410. 